\title{
Floristic Composition and Change in Species Diversity over Long Temporal Scales in Upper Bhotekoshi Hydropower Project Area in Nepal
}

\author{
Ramesh Prasad Bhatt*, Sarala Bhatt \\ Institute of Ecology and Environment, Kathmandu, Nepal \\ Email: *drrameshbhatta@gmail.com,rameshbhatta@yahoo.com
}

Received 17 October 2015; accepted 10 January 2016; published 13 January 2016

Copyright (C) 2016 by authors and Scientific Research Publishing Inc.

This work is licensed under the Creative Commons Attribution International License (CC BY). http://creativecommons.org/licenses/by/4.0/

\section{(c) (i) Open Access}

\begin{abstract}
Forest and vegetation of particular ecosystem is generally influenced by external factors especially from development activities. Nepal has been endowed with an immense variety of forest resources with its unique biodiversity. The current study is conducted in the temperate forest of central Nepal to compare the state of vegetation recorded during 1995 with the present condition. To identify floristic composition, species distribution and diversity, same location and same size of quadrates were selected in natural forest and planted or regenerated area as in previous study. Measurement and analytical tools for forest and vegetation reveled a total of 19 species and 341 individuals in 0.14 ha regenerated area and 18 species, 17 genera and 260 individuals in 0.16 ha, natural forest areas. However, in 1995, total 31 individuals of 20 woody species, 18 genera and 15 families were recorded within the sampling plots of 0.16 ha of natural forest. Moreover, Alnus nepalensis is found dominating regenerated area and Caryopteris odorata in natural forests whereas in 1995, Litsea chartacea and Maesa chisia were recorded dominant. The Shannon's diversity $H^{\prime}=$ 2.908, $\mathrm{E}=\mathbf{0 . 9 7 0}$ and Var $\mathrm{H}^{\prime}=\mathbf{0 . 0 0}$ and Simpsons $\mathrm{D}=\mathbf{0 . 0 2 7}$ recorded in 1995 is found to be with higher values when compared with the analysis of present study. Furthermore, in comparison to 1995 study, this study showed lower basal area and timber volume with declining species diversity. Although, the natural forest is found with higher species composition compared to rehabilitated forest, species of herbs and shrubs were found extensively growing.
\end{abstract}

\section{Keywords}

Floristic Composition, Changes in Species Diversity, Vegetation Analysis

\footnotetext{
${ }^{*}$ Corresponding author.
}

How to cite this paper: Bhatt, R.P. and Bhatt, S. (2016) Floristic Composition and Change in Species Diversity over Long Temporal Scales in Upper Bhotekoshi Hydropower Project Area in Nepal. American Journal of Plant Sciences, 7, 28-47. 


\section{Introduction}

The forests of the world play vital role in maintaining and balancing natural eco-system. These forest resources fulfill human demands by providing renewable raw materials and energy, maintain biodiversity and protect land and water resources. These resources are under degradation extensively due to increasing population pressure, agricultural and urban expansion, industrialization, infrastructure development and other disturbances.

In global scenario, Nepal allows many habitats and tremendous biodiversity and ecosystems representing $29 \%$ of forest resources. It holds less than $0.03 \%$ of earth surface which blessed with $1.3 \%$ (22,000 species) species of plants and animals embracing 49th position in the Worlds Biodiversity Index [1]. For richness of flowering plant species, Nepal represents 27th position in the world and 10th in Asia. At present, subsequent growing developmental activities and continuous pressures on forest resources cause rapid depletion and degradation of the resources. Forest and vegetation of particular ecosystem generally influenced by the external factors especially the man made development activities.

According to Clements, 1916 [2], Braun-Banquet, 1932 [3] and Odum, 1971 [4], vegetation is composed of certain distinct and fairly discrete plant communities. Odum 1971, further elaborate that the communities have a degree of internal organization which jointly modifies the environment with sharp delimitation from other communities.

The external environmental factors of disturbance suddenly change the composition of plant structures. The present vegetation composition of a particular ecosystem reflects the site conditions and disturbances over the time. To estimate environmental change at a given site with reference to different current vegetation comprising pristine or potential natural vegetation, a hemeroby concept was developed [5]-[8]. Because of the complex and nonlinear nature of ecosystems and unique ecological histories, that method is flawed as one cannot detect a pristine ecosystem in this changing world. Therefore, Reif, 2000 [9] suggested that the vegetation completely "natural" and pristine as well "potential natural" is only hypothetical.

Furthermore, as the species number found depends on the plot size studied (i.e. species-area relationship); the method cannot be used for cross scale evaluation. According to Karki, 1991 [10], Chaudhary and Kunwar, 2002 [11], human impact is the major cause leading varying degrees of biodiversity reduction in most of the forested areas in Nepal. For the effective conservation of such disturbed forest, it is important to understand the composition of the particular forest, effects of past disturbances, and the present impact of neighboring land use [12]). It is essential to study the phytosociological structure of such disturbed Himalayan forests to understand the distribution pattern of individual plant species with various girth classes, associations among other species, patterns of dispersion and various indices of diversity [13].

Several global vegetation mapping systems use temperature and moisture relations as predictors for vegetation types occurring in different areas [14] [15]. Similarly, based on temperature, moisture and rainfall, Nepal's forest and vegetation is classified into tropical, subtropical, temperate, sub alpine and alpine [16] [17].

Humankind development activities entail a change in land use, biodiversity and habitats, running the risk of potential destruction, degradation and fragmentation of natural habitats. Potential repercussions that could occur during construction activities can have temporary or permanent negative impacts on biodiversity and habitats with different intensity, magnitude and size depending on location, ecosystem, location and site size. The potential impact is largely depending on specific habitat conditions, species and the level of awareness of the people surrounding the natural environment. To protect and restore forest resources an integrated assessment tool is necessary to support decision making towards human impacts on forest biodiversity and their use [18]. To ensure that potential adverse impact of developments have been anticipated, addressed and integrated into decision making process so that the mitigation hierarchy be rightly applied [19].

Government of Nepal has applied EIA since 1993 with formulation of Environmental Impact Assessment Guideline and formally after endorsement of Environmental Protection Act and its Regulation 1997. Accordingly, EIA study suggested implementation of mitigation measures for impact area of upper bhotekoshi hydropower project. The comparison of data since 1995 feasibility study, 1997 EIA study and EIA monitoring period from 1998-2002 to this study analyzed variation in species composition and distribution. The existing forests of the study areas fulfill daily demand of firewood, litter, fodder and timber to support the livelihoods of rural communities, but similar other activities face pressure like clearance for agriculture, browsing by livestock, human-set fires, timber logging, and fuel wood extraction. The temperate forest and vegetation of the study area comprised with lower temperate mixed broad-leaved forest, riverine forests with association of Tona, Albizzia 
and Bombax and upper temperate mixed broad-leaved forest (Quercus-Rhododendron-Tsuga forest). Later on the study site was selected for planned development activities in and around of the forest areas. Previous studies experiencing high rates of forest loss and degradation as a result of over-exploitation and conversion of forest to other land uses in many developing countries [20]-[22].

Development activities cause impacts in the ecological processes, both at the landscape scale and the scale of individual forest patches which influence species composition and habitat characteristics at different scales. Restoration of such disturbed ecosystem can be achieved through establishment of native tree species including artificial establishment and/or encouragement of natural regeneration, in a wide range of site conditions (Newton et al. 2009). These restoration practices of forests take a great deal of time to recover following disturbance. Whereas, total stem number, basal area, or leaf area index rapidly recover the structural characteristics and latesuccessional species composition or the number of large trees for variables characterizing old-growth conditions require a timescale of centuries to re-establish [23]-[26].

This study relates the impacts and changing pattern of forest and vegetation during the implementation and operation of the development activities. The collected ecological data in phased wise manner and different time period are valuable for reconstructing early environmental and vegetation community conditions and examination of changes towards vegetation communities and disturbance regimes. The data's collected and experimentally calculated over decadal and longer temporal scales were free from error.

\section{Study Area}

The study area lies between $27^{\circ} 54^{\prime} 87^{\prime \prime N}$ latitude and $85^{\circ} 55^{\prime} 51$ "E longitude along the Botekoshi River within the Tatopani and Phulpingkatti Villages Development Committees (VCDs) of Sindhupalchowlk district, Nepal (Figure 1). The Bhotekoshi River originates from the Tibet Autonomous region of China and set steep across the high Himalayan zone with extreme steeps slopes, unique vegetation cover and narrow valleys. Along the run of the river Bhotekoshi, dam and powerhouse sites of upper bhotekoshi hydropower Project (35 MW) are located within an elevation range of $1440 \mathrm{~m}$ and $1285 \mathrm{~m}$ asl. However, in the closer surrounding areas of the Bhotekoshi project site, altitude varies from about $1250 \mathrm{~m}$ to $3500 \mathrm{~m}$. In the study area and its surroundings, air temperature rises usually during the pre-monsoon period from February to May and decreases during post monsoon period from October to January, respectively. The mean annual precipitation in the study site and its surrounding area vary from $3000 \mathrm{~mm}$ to $3500 \mathrm{~mm}$, of which $2500 \mathrm{~mm}$ to $3000 \mathrm{~mm}$ occur during monsoon.

The proposed study area Botekoshi River basin was described rich forest and vegetation except on steep slope east to Larcha, across the River (EIA study of Botekoshi hydropower project, IUCN 1995 [27]). The study identified total 11,345 ha forest area was recorded of two VDCs (6407 ha in Phulpingkatti, and 4938 ha in Tatopani VDC) of project influence area. The grasslands comprise 725 ha at Phulpingcutti VDC and 1762 ha at Tatopani VDC respectively. During EIA study Larcha forest up along the Bhairabkunda khola recorded high species diversity, followed by Pansherpu forests. The Larcha and Pansherpu forests are on north slopes, and moist indicate higher number of species. However, Khajilung community forest located within the steep west facing slope reported lower number of species.

The lower temperate mixed broad-leaved forest along the Bhotekoshi river basin recorded dominant evergreen laurels comprising species of Actinodaphne anguistifolia, Persea ghamblei, Litsea elongeta, Neolitsea spp, Cinnamomoum spp and Dodecadenia spp with other associated species in the forest species of Macarange, Leucosceptrum, Michillia spp, Acer, Dynplocos, Caryoteris and Measa sps. Along the Bairabkunda Khola, above Larcha comprised degraded riverine forests. This forest dominated by the species of Albiizzia, Bombex, Macarange and Alnus spp towards the lower part. As one ascends the Bairabkunda Khola, again the lower temperature mixed broad leaved forest with evergreen laurels were reported. Species of Wendlandia, Enelhardia, Michelia, Caryoptries and Measa were reported as major associate species in this forest. These characteristics features of forest and vegetation studied in pre and post periods of EIA surroundings of upper Bhotekoshi hydropower project area.

\section{Materials and Methods}

For this study, two types of forest, natural and planted or regenerated forest and vegetation (disturbed slopes by the projects) were selected. The natural forest comprises community forest determined as influence zone of the project in EIA study. The planted forests are the disturbed slope of the study area with adoption of the mitigation 


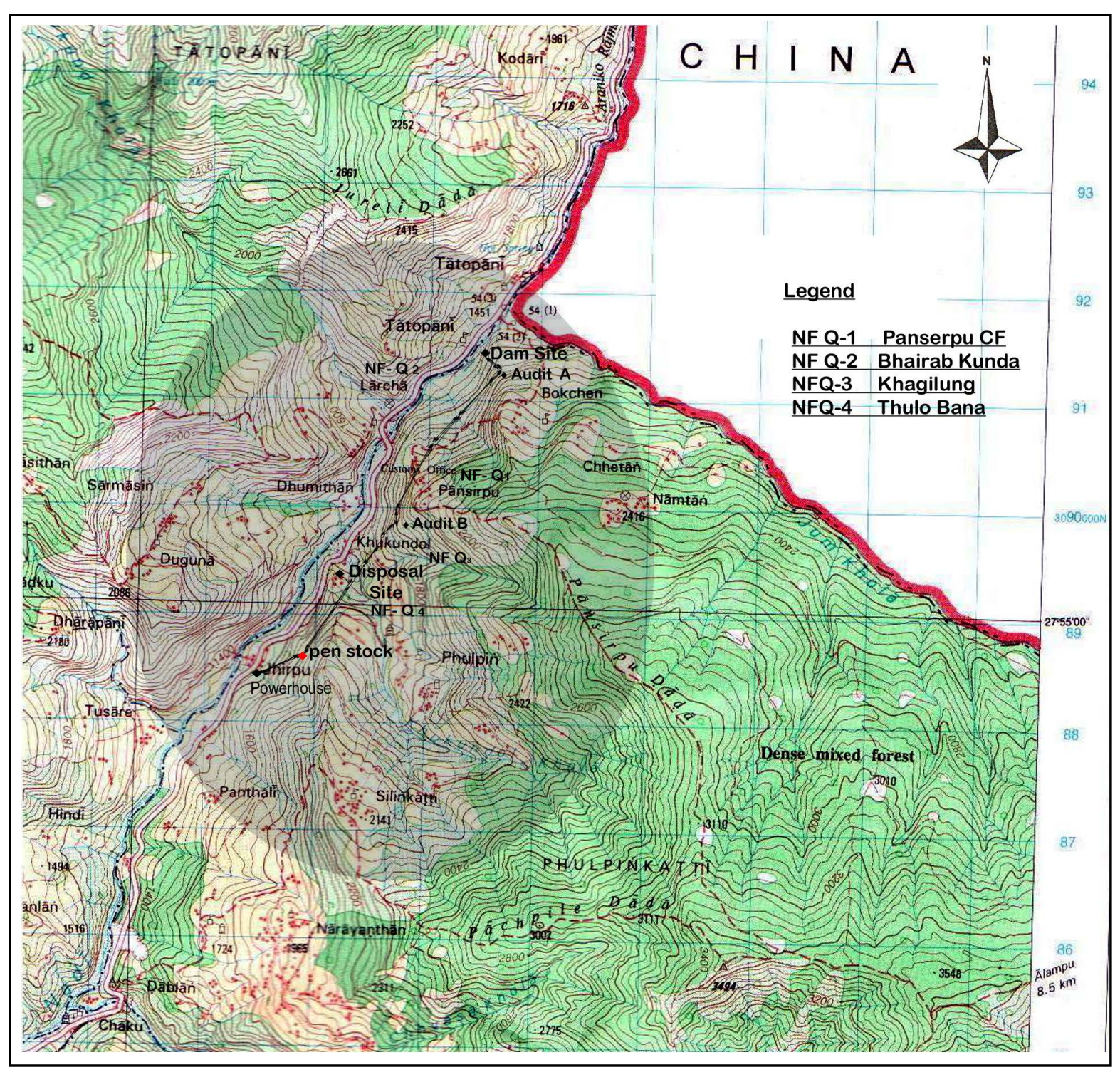

Figure 1. Study area.

measures. To enumerate and identify floristic composition, community sampling units were established. Quadrate, transect and point sampling methods were used with the size of $10 \times 10 \mathrm{~m}^{2}$ for regeneration or planted area and $20 \times 20 \mathrm{~m}^{2}$ for natural forest areas. Several blocks or squares (quadrates) with definite size were established in the natural and project disturbed area to identify total number of trees, shape and size as described by Mueller-Dombois and Ellenberg, 1974 [28]. The Spatial data layers like boundary, drainage pattern, contours (altitude, slope and aspect), and vegetation types were extracted from topo sheet of the project area, at the scale of 1:50,000 (Figure 1 ).

Suunto Hypsometer was used for measuring height of the trees. Likewise, for measuring diameter and circumferences, instruments like Caliper, Finnish Caliper and measuring tape were employed. For McHarg overlays, Geographical Information Systems (GIS), GPS was used. The diameter was measured at $1.30 \mathrm{~m}$ aboveground. In case of normal trees, measurement was done horizontally and strait across the stem for leaning trees. Likewise for forking trees, forks above $1.30 \mathrm{~m}$ were taken into account as two trees.

The transect stands of an area of $100 \mathrm{~m}^{2}$ size (0.01 hectare), having $10 \mathrm{~m}$ length and breadth each, were fixed by measuring tape. Planted area was estimated dividing the reforested area in 10 ha blocks $(200 \times 500 \mathrm{~m})$. Planted area less than 10 ha was divided in 1 ha block $(100 \mathrm{~m} \times 100 \mathrm{~m})$. Similarly, in natural forests around at 
dame site, adit a, adit b, and powerhouse area, $20 \times 20 \mathrm{~m}^{2}$ quadrate was established. Trees with girth exceeding $10 \mathrm{~cm}$ diameter at breast height ( $\mathrm{dbh}$, at $1.37 \mathrm{~m}$ above the ground) were measured. The height of standing trees was measured by means of clinometers. Finally, vegetation analysis was done by adopting releve analysis approach (M. Dombosis and Ellenberg, 1974). The plant species of all growth forms within each quadrate were enumerated by using a simple matrix. The diameter at breast height and height of each trees including cut stumps, having more than $10 \mathrm{~cm}$ circumference were measured by using measuring tape and calibrated $1 \mathrm{~m}$ long pole, respectively.

Density, frequency, basal area and their relative values of tree species were calculated following Mueller-Dombois and Ellenberg, 1974. Botanical name and author citation were written as per Department of Plant Resources 2000 [29]. In addition to qualitative data regarding community forests, interviews and group discussions were conducted. In order to assess the general condition and vegetation structure of the forest, a density-diameter histogram was developed.

The species area curve of each community forests was calculated by randomly adding up the number of tree species in each quadrate. " $S$ ", or species richness, was determined following Whittaker, 1976 [30] by tabulating the number of woody species in each plot. Shannon-Weiner's diversity index " $H$ " (Shannon and Weiner [31]), concentration of dominance " $D$ " (Simpson [32]) and Hill diversity numbers $\mathrm{N}_{0}, \mathrm{~N}_{1}$ and $\mathrm{N}_{2}$ (Hill [33]) were computed.

Simpson’s index “ $D$ ” was calculated using the formula

$$
D=1-\sum p_{i}^{2}
$$

where, $p_{i}$ is the relative density.

Shannon-Weiner's diversity index " $H$ " was calculated using the formula

$$
H=-\sum p_{i} \log p_{i}
$$

where, $p_{i}$ represents the proportional abundance of the species in the community.

Hill diversity indices were calculated using the following formulae:

Number 0: $\mathrm{N}_{0}=\mathrm{S}$, where $\mathrm{S}$ is the total number of species

Number 1: $\mathrm{N}_{1}=\mathrm{eH}$, where " $\mathrm{H}$ " is the Shannon's index

Number 2: $\mathrm{N}_{2}=1 / \mathrm{D}$, where "D" is Simpson's index

Composition and distribution pattern of vegetation and forest types and change of environmental gradients in the project area was studied with extensive literature [34] and collection/measurement of field data's. The density of tree per ha, basal area and volume estimation of trees were calculated by using the following formulas [35].

$$
\begin{aligned}
& \text { Density } / \text { ha }=\frac{\text { Total no. of Individual Spp } \times 10000 \mathrm{~m}^{2}}{\text { Total numbers of quadrates studied } \times \text { Area of Quadrates }} \\
& \mathrm{BA}\left(\mathrm{m}^{2}\right)=(\text { circumference }) 2 / 4 \times 3.1416 \\
& \mathrm{~V}\left(\mathrm{~m}^{3}\right)=\mathrm{BA} \times \mathrm{h} / 2
\end{aligned}
$$

where, $\mathrm{V}=$ Volume, $\mathrm{BA}=$ Basal Area $\left(\mathrm{m}^{2}\right), \mathrm{h}=$ Height $(\mathrm{m})$.

\section{Species area curve estimate}

The plots of the studied area were examined estimating Species Area Curve with cumulative sampling area (x-axis) versus the total number of species found in the quadrate samplings (y-axis). The species area curve was used as a log-log relationship [36].

$$
\log (S)=a+\log (A)
$$

where; $S=$ Number of species (= species richness); $A=$ Area sampled; $a=$ y-intercept of the regression.

\section{Results}

\subsection{Regenerated and Planted Areas}

The composition and distribution for plantation or regeneration area (disturbed slopes of the project area) are 
given below:

\subsubsection{Sampling Size and Species Composition}

Total 8 quadrates of $10 \times 10 \mathrm{~m}^{2}$ were established in the headwork area including above wire site, dam site, access road and Adit A. Similarly, 4 quadrates in Adit B and 2 quadrates of similar size at powerhouse site were selected. These areas were the disturbed slopes of construction stage which were rehabilitated as per mitigation measures after construction. Altogether, 14 quadrates of $10 \times 10 \mathrm{~m}^{2}$ covering 0.14 ha area were studied representing total of 19 species, 15 genera, 13 families and 341 individuals (Table 1).

\subsubsection{Floristic Composition and Distribution}

In the study area, floristic composition and distribution comprises nearly 45 tree and shrubs representing 15 species belonging to 15 genera and 13 families. Among them, 4 new planted species were identified at powerhouse site. The under-storey vegetation below the girth limit of $10 \mathrm{~cm}$ revealed almost $86 \%$ of the total numbers of species confined in the forest while $14 \%$ represented abundance of shrubs species. The abundance of the species identified during the feasibility study in 1995 is quiet different as this study found single species of Alnus nepalensis (Bhatt, 2010 [37]) a regenerated species (Table 2).

Table 1. Species composition of plantation or regeneration area.

\begin{tabular}{lccccc}
\hline \multicolumn{1}{c}{ Location } & No. of Quadrates Size $\left(10 \times 10 \mathrm{~m}^{2}\right)$ & Total Species & Total Genera & Total Individuals & Total Area \\
\hline Dam Site & 8 & 10 & 10 & 174 & $800 \mathrm{~m}^{2}(0.08 \mathrm{ha})$ \\
Adit B & 4 & 2 & 2 & 142 & $400 \mathrm{~m}^{2}(0.04 \mathrm{ha})$ \\
Powerhouse & 2 & 7 & 7 & 25 & $200 \mathrm{~m}^{2}(0.01 \mathrm{ha})$ \\
Total & 14 & $19(15)$ & $19(15)$ & 341 & $1300 \mathrm{~m}^{2}(0.13 \mathrm{ha})$ \\
\hline
\end{tabular}

Table 2. Composition and distribution of tree species in 14 sampling plots.

\begin{tabular}{|c|c|c|c|c|c|c|c|c|c|c|c|c|c|c|c|c|c|c|}
\hline \multirow{2}{*}{ SN } & \multirow{2}{*}{ Scientific Name } & \multirow{2}{*}{ Nepali Name } & \multirow{2}{*}{ Family } & \multicolumn{14}{|c|}{ Abundance of Species in Sampling Plots } & \multirow[t]{2}{*}{ Total } \\
\hline & & & & 1 & 2 & 3 & 4 & 5 & 6 & 7 & 8 & 9 & 10 & 11 & 12 & 13 & 14 & \\
\hline 1 & Actinodaphne anguistifolia & Jhankri Kath & Lauraceae & - & - & - & - & + & - & - & - & - & - & - & - & - & - & 1 \\
\hline 2 & Albizzia chinensis & Siris & Leguminosae & - & - & - & - & - & - & - & - & - & - & - & - & + & + & 2 \\
\hline 3 & Alnus nepalensis & Utis & Betulaceae & + & + & + & + & + & + & + & + & + & + & + & + & + & - & 13 \\
\hline 4 & Arundinaria falcata & Nigalo & Poaceae & - & - & - & + & + & - & - & - & - & - & - & - & - & - & 2 \\
\hline 5 & Choerospondias axillaris & Lapsi & Anarcadaceae & - & - & - & - & - & - & - & - & - & - & - & - & - & + & 1 \\
\hline 6 & Ficus nerrifolia & Nimaro & Moraceae & - & - & - & - & - & - & - & - & - & - & - & - & + & - & 1 \\
\hline 7 & Fraxinus floribunda & Lakure & Oleaceaae & - & - & - & - & - & - & - & - & - & - & - & - & + & - & 1 \\
\hline 8 & Golko Rukh & Uniden. & Rannanculaceae & - & + & + & - & - & - & - & - & - & - & - & - & - & - & 2 \\
\hline 9 & Juglans regia & Okhar & Juglandaceae & - & - & - & - & + & - & - & - & - & - & - & - & - & - & 1 \\
\hline 10 & Leucosceptrum canum & Dhursul & Labiateae & - & - & - & - & - & - & - & - & + & + & + & + & - & - & 4 \\
\hline 11 & Litsea elongeta & Pahale & Lauraceae & - & - & - & - & + & - & - & - & - & - & - & - & - & - & 1 \\
\hline 12 & Macaranga denticulata & Malato & Euphorbiceae & + & + & + & + & + & - & - & - & - & - & - & - & - & - & 5 \\
\hline 13 & Maesa chisia & Bilaone & Myrsinaceae & + & + & + & + & + & + & - & + & - & - & - & - & - & + & 8 \\
\hline 14 & Rhus javanica & Bhalayo & Anacardaceae & - & - & - & - & + & - & - & - & - & - & - & - & + & - & 2 \\
\hline 15 & Toona ciliata & Tooni & Meliaceae & - & - & - & - & - & - & - & - & - & - & - & - & - & - & 1 \\
\hline \multicolumn{4}{|c|}{ Total } & 3 & 4 & 4 & 4 & 10 & 2 & 1 & 3 & 2 & 2 & 2 & 2 & 5 & 3 & 45 \\
\hline
\end{tabular}

Note: + = Presence, - = Absence. 


\subsubsection{Species Area Curve}

The species-area curve, expressed mathematically, shows the increasing trend of species abundance to certain limits of constant followed by prediction effects with species survival rates (Figure 2).

\subsubsection{Species Composition}

Trees and shrub species in sampling plots were identified in 3 main sampling units, Dam site, Adit B and Powerhouse area with sampling plots of 8, 4 and 2 respectively. 174 individuals belonging to 10 species recorded in dam site with highest number (41.37\%) of Alnus nepalensis in all plots. The individual tree species Maesa chisia (32.18\%), and Macaranga denticulata (18.96\%) followed with shrub species Arundinaria falcate (3.44\%). Single individuals of each Actinodaphne anguistifolia, Litsea elongeta, Rhus javanica, Juglans regia and Toona ciliata represented the lowest (0.57\%) number (Table 3(a)). In 4 plots at Adit B, 142 individuals belonging to 2 species were identified. Among identified species, $57.74 \%$ was Leucosceptrum canum while $42.25 \%$ was Alnus nepalensis (Table 3(b)). Among 2 plots established at powerhouse area, abundance of 7 planted species with total number of 25 individuals was found (Table 3(c)).

\subsubsection{Species Diversity}

The species diversity of Simpsons Index (D) showed 3.243 suggesting higher diversity in the area of 1 ha. Likewise, Shannon-Weiner index of species diversity $(\mathrm{H})$ was 1.963. However, the value exceeds the maximum value assumed for $\mathrm{H}$ (i.e. $\log \mathrm{S}$ ); it is not surprising since the forest area is highly diverse (Table 4).

\subsubsection{Basal Area and Timber Volume}

Total 79 individuals of trees belonging to 6 species and 6 genera were recorded in 10 sampling quadrates. The highest 13 individuals of Alnus nepalensis were recorded in plot number 7 with $3.12 \mathrm{~m}^{2}$ basal area and $18.53 \mathrm{~m}^{3}$ timber volume while the lowest number of individuals were recorded in plot number 2,3 , 4, and 5 . The individuals with the highest basal area $\left(31.27 \mathrm{~m}^{2}\right)$ and timber volume $\left(445.97 \mathrm{~m}^{3}\right)$ is observed in plot 2 and the lowest basal area $\left(0.29 \mathrm{~m}^{2}\right)$ and timber volume $\left(1.68 \mathrm{~m}^{3}\right)$ was found in plot number 6 (Table 5). The highest BA and volume was found among the older tree species. Alnus nepalensis, a regenerated species, found in all disturbed slopes of the area. The disturbed slopes at Naukilo, headwork area and Powerhouse site were found rehabilitated through plantation of Vetiveria zizaniodes and Pennisetus puroureum whereas disposal areas of the project were found unplanted exposing boulders rocks as open grazing area. Thus, the disturbed slopes are not restored in terms of vegetation cover as recorded before the project construction.

\subsection{Natural Forest Areas}

The study area comprises lower and upper temperate broad leaved and deciduous riverine forest. The main channel of Bhotekoshi River with its tributaries mixes in Jungkhola above dam site, Bhairabkunda khola below dam site and Khukundol khola near Adit B where sparse riverine forest exists. The natural forest represents following range of floristic composition and species distribution.

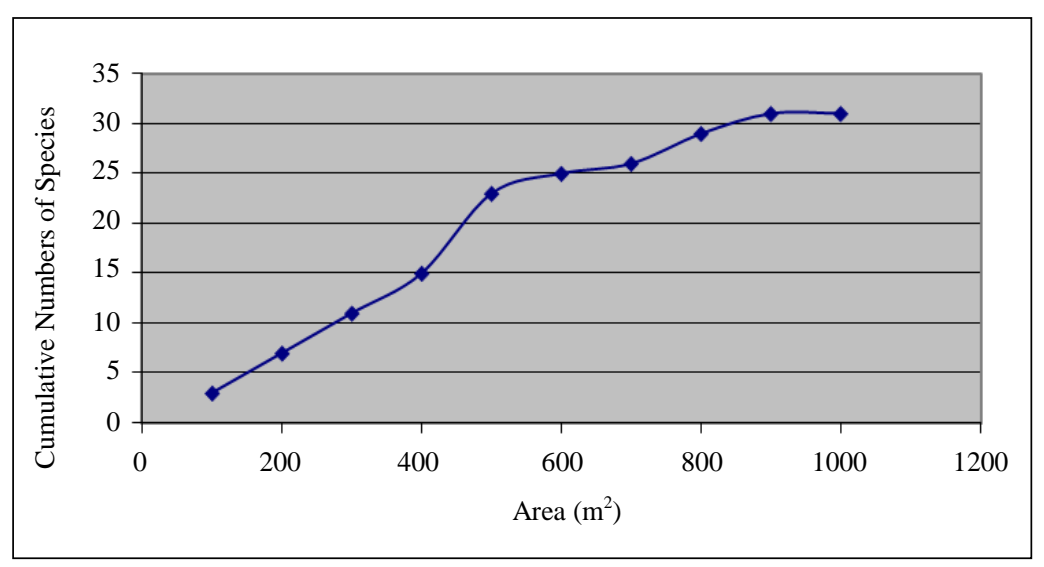

Figure 2. Species area curve. 
Table 3. Numbers of tree and shrub species in sampling plots $\left(10 \times 10 \mathrm{~m}^{2}\right)$.

\begin{tabular}{|c|c|c|c|c|c|c|c|c|c|c|c|}
\hline \multicolumn{12}{|c|}{ (a) Dam Site (Headwork Area) } \\
\hline \multirow{2}{*}{ SN } & \multirow{2}{*}{ Scientific Name } & \multirow{2}{*}{ Nepali Name } & \multicolumn{8}{|c|}{ Sampling Plots* } & \multirow[t]{2}{*}{ Total } \\
\hline & & & 1 & 2 & 3 & 4 & 5 & 6 & 7 & 8 & \\
\hline 1 & Alnus nepalensis & Utis & 9 & 7 & 9 & 7 & 2 & 12 & 13 & 13 & 72 \\
\hline 2 & Macaranga denticulata & Malato & 6 & 16 & 4 & 4 & 3 & 0 & 0 & 0 & 33 \\
\hline 3 & Maesa chisia & Bilaone & 4 & 2 & 10 & 25 & 5 & 6 & 0 & 4 & 56 \\
\hline 4 & Unidentified spp & Golko rukh & 0 & 1 & 1 & 0 & 0 & 0 & 0 & 0 & 2 \\
\hline 5 & Arundinaria falcata & Nigalo & 0 & 0 & 0 & 1 & 5 & 0 & 0 & 0 & 6 \\
\hline 6 & Actinodaphne anguistifolia & Jhankri kath & 0 & 0 & 0 & 0 & 1 & 0 & 0 & 0 & 1 \\
\hline 7 & Litsea elongeta & Pahale & 0 & 0 & 0 & 0 & 1 & 0 & 0 & 0 & 1 \\
\hline 8 & Rhus javanica & Bhalayo & 0 & 0 & 0 & 0 & 1 & 0 & 0 & 0 & 1 \\
\hline 9 & Juglans regia & Okhar & 0 & 0 & 0 & 0 & 1 & 0 & 0 & 0 & 1 \\
\hline 10 & Toona ciliata & Tooni & 0 & 0 & 0 & 0 & 0 & 0 & 0 & 1 & 1 \\
\hline \multicolumn{3}{|c|}{ Total } & 19 & 26 & 24 & 37 & 19 & 18 & 13 & 18 & 174 \\
\hline \multicolumn{12}{|c|}{ (b) Adit B (Between and within access road) } \\
\hline 1 & Alnus nepalenesis & Utis & 9 & 17 & 14 & 20 & - & - & - & - & 60 \\
\hline 2 & Leucosceptrum canum & Dhursul & 10 & 25 & 12 & 35 & - & - & - & - & 82 \\
\hline \multicolumn{3}{|c|}{ Total } & 19 & 42 & 26 & 55 & - & - & - & - & 142 \\
\hline \multicolumn{12}{|c|}{ (c) Powerhouse Area (Access road and Penstock area) } \\
\hline 1 & Alnus nepalensis & Utis & 8 & 0 & - & - & - & - & - & - & 8 \\
\hline 2 & Ficus nerrifolia & Nimaro & 1 & 0 & - & - & - & - & - & - & 1 \\
\hline 3 & Fraxinus floribunda & Lakure & 1 & 0 & - & - & - & - & - & - & 1 \\
\hline 4 & Rhus javanica & Bhalayo & 1 & 0 & - & - & - & - & - & - & 1 \\
\hline 5 & Albizzia chinensis & Siris & 5 & 4 & - & - & - & - & - & - & 9 \\
\hline 6 & Maesa chisia & Bilaone & 0 & 3 & - & - & - & - & - & - & 3 \\
\hline 7 & Choerospondias axillaris & Lapsi & 0 & 2 & - & - & - & - & - & - & 2 \\
\hline & Total & & 16 & 9 & - & - & - & - & - & - & 25 \\
\hline Note: & $\begin{array}{l}\text { pling Sites: Quadrate numbe } \\
\text { ilo; }{ }^{\#} \text { Quadrate number: } 1 \text { = }\end{array}$ & $\begin{array}{l}\text { A, } 4-5=\text { Below } \\
\text { Powerhouse, } 2=1\end{array}$ & 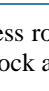 & & A, 6 & elow & & & & 7 - & $=$ Dam site \\
\hline & ecies Diversity Index & Da & & & Adi & & & & verho & se Site & \\
\hline & apsons index (D) & & & & 1.9 & & & & 4.4 & & \\
\hline & annon’s Diversity (H) & & & & 0.9 & & & & 2.2 & & \\
\hline & annon’s Max (Hmax) & & & & 1 & & & & 2.8 & & \\
\hline & ecies equitability (E) & & & & 0.9 & & & & 0.8 & & \\
\hline
\end{tabular}


Table 5. Quadrate wise basal area and timber volume of tree species.

\begin{tabular}{|c|c|c|c|c|c|c|c|}
\hline \multicolumn{8}{|c|}{ Quadrate 1: Adit A } \\
\hline SN & Scientific Name & Numbers & Gbh (cm) & GBH (m) & Height (m) & BA $\left(\mathbf{m}^{2}\right)$ & Volume $\left(\mathbf{m}^{3}\right)$ \\
\hline 1 & Alnus nepalensis & 8 & $15-40$ & $0.15-0.4$ & $7-9$ & 0.45 & 1.86 \\
\hline \multirow[t]{2}{*}{2} & Macaranga denticulata & 2 & $30-40$ & $0.3-0.4$ & $9-10$ & 0.2 & 0.95 \\
\hline & & Total & & & & 0.64 & 2.81 \\
\hline \multicolumn{8}{|c|}{ Quadrate 2: Adit A (Golko Rukh) } \\
\hline 1 & Alnus nepalensis & 2 & $30-65$ & $0.3-65$ & $5-10$ & 0.4 & 1.83 \\
\hline 2 & Unidentified spp (Golko rukh) & 1 & 6.2 & 6.2 & 29 & 30.18 & 437.54 \\
\hline \multirow[t]{2}{*}{3} & Macaranga denticulata & 2 & $60-72$ & $0.6-0.72$ & $15-22$ & 0.69 & 6.6 \\
\hline & & Total & & & & 31.27 & 445.97 \\
\hline \multicolumn{8}{|c|}{ Quadrate 3: Adit A (Golko Rukh II) } \\
\hline 1 & Alnus nepalensis & 1 & 56 & 0.56 & 7 & 0.25 & 0.86 \\
\hline \multirow[t]{2}{*}{2} & Unidentified spp (Golko rukh) & 1 & 3.45 & 3.45 & 32 & 9.34 & 149.5 \\
\hline & & Total & & & & 9.59 & 150.36 \\
\hline \multicolumn{8}{|c|}{ Quadrate 4: Adit A (Access road edge of the river) } \\
\hline 1 & Unidentified spp (Golko rukh) & 4 & $15-1$ & $0.8-1$ & $9-25$ & 2.01 & 21.06 \\
\hline \multicolumn{8}{|c|}{ Quadrate 5: Below Access Road } \\
\hline 1 & Juglans regia & 1 & 1.5 & 1.5 & 6 & 1.77 & 5.3 \\
\hline 2 & Actinodaphne anguistifolia & 1 & 16 & 0.16 & 5 & 0.02 & 0.05 \\
\hline 3 & Macaranga denticulata & 3 & $12-15$ & $0.2-0.15$ & $9-10$ & 0.06 & 0.29 \\
\hline 4 & Alnus nepalensis & 2 & $11-60$ & $1.1-0.60$ & $12-20$ & 1.23 & 11.19 \\
\hline \multirow[t]{2}{*}{5} & Litsea elongeta & 1 & 65 & 0.65 & 6 & 0.33 & 0.99 \\
\hline & & Total & & & & 3.41 & 17.52 \\
\hline \multicolumn{8}{|c|}{ Quadrate 6: Below Dam site above access Road } \\
\hline 1 & Alnus nepalensis & 5 & $10-50$ & $0.1-0.25$ & $9-12$ & 0.29 & 1.68 \\
\hline \multicolumn{8}{|c|}{ Quadrate 7: Along dam site } \\
\hline 1 & Alnus nepalensis & 13 & $36-72$ & $0.36-0.72$ & $7-14$ & 3.12 & 18.53 \\
\hline \multicolumn{8}{|c|}{ Quadrate 8: Upstream Left-hand site dam site } \\
\hline 1 & Alnus nepalensis & 7 & $16-65$ & $0.16-0.65$ & $7-15$ & 0.65 & 4.18 \\
\hline \multicolumn{8}{|c|}{ Quadrate 9: Audit B access road } \\
\hline 1 & Alnus nepalensis & 8 & $15-65$ & $0.15-0.65$ & 10 & 1.54 & 10.65 \\
\hline \multicolumn{8}{|c|}{ Quadrate 10: Audit B access road } \\
\hline 1 & Alnus nepalensis & 17 & $24-48$ & $0.24-0.48$ & $5-15$ & 1.72 & 8.9 \\
\hline
\end{tabular}




\subsubsection{Sampling Size and Species Composition}

Total 4 quadrates $20 \times 20 \mathrm{~m}^{2}$ sampling size was selected within the 4 natural forest areas. These forest areas were categorized in EIA study as a direct impact zone of the project. All quadrates were established in the same size and locations covering 0.16 ha area as measured during EIA study in 1995. A total 18 species, 17 genera and 260 individuals of different forest species with lower numbers of species and higher numbers of individuals were observed during this study. While, the species composition recorded during EIA study were 20 species 18 genera and 88 individuals (Table 6).

\subsubsection{Floristic Composition and Distribution}

Among the 18 species recorded in 4 quadrates in 0.16 ha area, Panserpu community forest above Adit $\mathrm{A}$ of the project showed the highest (13) number of species, while, Khajilung and Bhairabkunda Larcha forests showed 10 and 8 species respectively. The lowest of 5 species was found in the Thuloban CF above disposal site of the project (Table 7).

\subsubsection{Species Area Curve}

The species-area curve mathematically showed the increasing trend of species to certain limits of constant during EIA study in 1995 and this study (Figure 3).

\subsubsection{Species Composition}

The dominance of 4 species (Caryopteris odorata, Alnus nepalensis, Acer oblongum, Litsea elongeta), together with their contribution of $58.4 \%$ of the total stand density indicates utilizing the majority of forest space and resources (Table 7). Besides that among 18 total species observed 3 of them found belonging to Lauraceae family (Table 8).

\subsubsection{Species Diversity}

Simpsons Index (D) of species diversity was 0.0397, suggesting higher diversity in 1ha area. Likewise, Shannon-Weiner index of species diversity $(\mathrm{H})$ was found 2.798; however, Shannon's Max (Hmax) value is 2 and Species equitability (E) 0.9683 . The value obtained for Simpson's index of diversity is not surprising as the forest area is highly diverse (referring to the result from y). As shown below in the Table 9, Schima wallichii and Caryopteris odorata showed the highest abundance of $11.11 \%$ while Pinus wallichiana, Actinodaphne anguistifolia, Albizzia chinensis, Macaranga denticulate, Myrica esculanta Pinus wallichiana showed the lowest species abundance of $2.77 \%$.

\section{Table 6. Sampling coverage and species composition.}

\begin{tabular}{|c|c|c|c|c|c|c|}
\hline SN & Location & No of Quadrates/Size $\left(20 \times 20 \mathrm{~m}^{2}\right)$ & Total Species & Total Genera & Total Individuals & Total Area (ha) \\
\hline \multicolumn{7}{|c|}{ During EIA 1995} \\
\hline 1 & Panserpu & 1 & 11 & $9-2$ & 38 & $400 \mathrm{~m}^{2}(0.04)$ \\
\hline 2 & Kajilung & 1 & 3 & 3 & 10 & $400 \mathrm{~m}^{2}(0.04)$ \\
\hline 3 & Bhairabkunda & 1 & 5 & 5 & 12 & $400 \mathrm{~m}^{2}(0.04)$ \\
\hline 4 & Thuloban & 1 & 1 & 1 & 28 & $400 \mathrm{~m}^{2}(0.04)$ \\
\hline & Total & 4 & 20 & 18 & 88 & $1600 \mathrm{~m}^{2}(0.16)$ \\
\hline \multicolumn{7}{|c|}{ During this study } \\
\hline 1 & Panserpu & 1 & 13 & 13 & 111 & $400 \mathrm{~m}^{2}(0.04)$ \\
\hline 2 & Kajilung & 1 & $13+2$ & $13+2$ & 43 & $400 \mathrm{~m}^{2}(0.04)$ \\
\hline 3 & Bhairabkunda & 1 & $15+2$ & $15+2$ & 51 & $400 \mathrm{~m}^{2}(0.04)$ \\
\hline 4 & Thuloban & 1 & $17+1$ & $17+0$ & 55 & $400 \mathrm{~m}^{2}(0.04)$ \\
\hline & Total & 4 & 18 & 17 & 260 & $1600 \mathrm{~m}^{2}(0.16)$ \\
\hline
\end{tabular}


Table 7. Number of tree and shrub species in sampling plots $\left(20 \times 30 \mathrm{~m}^{2}\right)$.

\begin{tabular}{|c|c|c|c|c|c|c|c|c|c|}
\hline \multirow[b]{2}{*}{ SN } & \multirow[b]{2}{*}{ Scientific Name } & \multirow[b]{2}{*}{ Nepali Name } & \multirow[b]{2}{*}{ Family } & \multicolumn{6}{|c|}{ Sampling plots } \\
\hline & & & & Plant Form & 1 & 2 & 3 & 4 & Total \\
\hline 1 & Alnus nepalensis & Utis & Betulaceae & Tree & - & + & + & - & 2 \\
\hline 2 & Acer oblongum & Firfere & Aceraceae & Tree & + & - & - & + & 2 \\
\hline 3 & Actinodaphne anguistifolia & Jhankri kath & Lauraceae & Tree & + & - & - & - & 1 \\
\hline 4 & Albizzia chinensis & Siris & Leguminosae & Tree & - & - & + & - & 1 \\
\hline 5 & Arundinaria falcata & Nigalo & Poaceae & Shrub & + & + & - & - & 2 \\
\hline 6 & Caesalpinia decapitala & Arilokanda & Leguminosae & Shrub & + & - & + & - & 2 \\
\hline 7 & Caryopteris odorata & Mohani & Verbinaceae & Tree & + & + & + & + & 4 \\
\hline 8 & Litsea elongeta & Pahale & Lauraceae & Tree & + & - & + & - & 2 \\
\hline 9 & Macaranga denticulata & Malato & Euphorbiaceae & Tree & + & - & - & - & 1 \\
\hline 10 & Maesa chisia & Bilaone & Myrsinaceae & Shrub & + & + & + & - & 3 \\
\hline 11 & Myrica esculanta & Kafal & Myricaceae & Tree & - & + & - & - & 1 \\
\hline 12 & Persea ghamblei & Kathekaulo & Lauraceae & Tree & + & - & + & - & 2 \\
\hline 13 & Pinus wallichiana & Sallo & Pinanceae & Tree & - & - & - & + & 1 \\
\hline 14 & Rhus javanica & Bhakmilo & Anarcadaceae & Tree & + & - & + & - & 2 \\
\hline 15 & Rhus succedanes & Bhalyao & Anarcadaceae & Tree & + & + & - & - & 2 \\
\hline 16 & Schima wallichii & Chilaone & Theaceae & Tree & + & + & + & + & 4 \\
\hline 17 & Symplocus pyrifolia & Kharane & Symplocaceae & Tree & - & - & + & + & 2 \\
\hline \multirow[t]{2}{*}{18} & Toona ciliata & Tooni & Meliaceae & Tree & + & + & - & - & 2 \\
\hline & & Total & & & 13 & 8 & 10 & 5 & 36 \\
\hline
\end{tabular}

Note: 1 = Panserpu, 2 = Bhairabkunda, 3 = Khajilung, 4 = Thuloban, $+=$ Presence, $-=$ Absence.

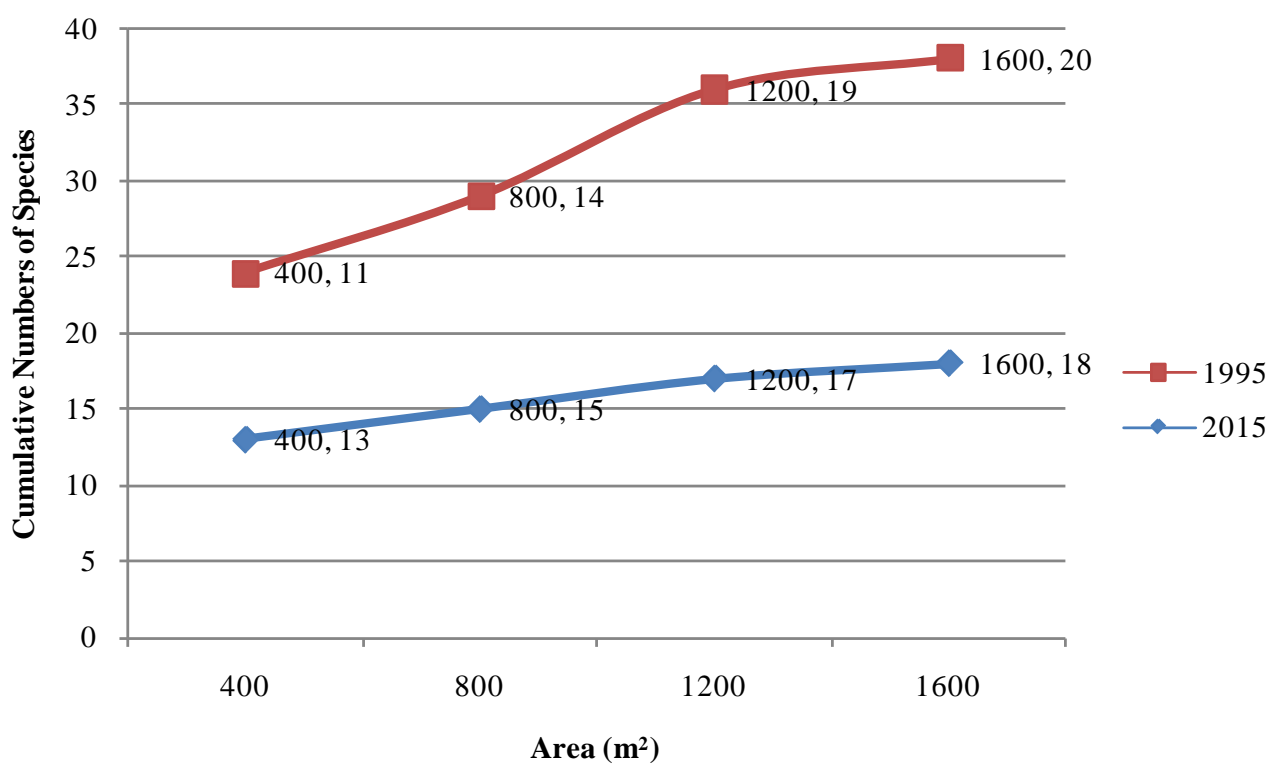

Figure 3. Species area curve. 
Table 8. Density, relative density and abundance of tree and shrub species in sampling plots $\left(30 \times 20 \mathrm{~m}^{2}\right)$.

\begin{tabular}{|c|c|c|c|c|c|c|c|c|c|}
\hline \multirow[b]{2}{*}{ SN } & \multirow[b]{2}{*}{ Scientific Name } & \multicolumn{4}{|c|}{ Sampling Plots } & \multirow{2}{*}{ Total } & \multirow{2}{*}{$\begin{array}{l}\text { Density } \\
\text { Per plot }\end{array}$} & \multirow{2}{*}{ Relative Density } & \multirow{2}{*}{ Abundance } \\
\hline & & 1 & 2 & 3 & 4 & & & & \\
\hline 1 & Alnus nepalensis & 0 & 8 & 19 & 0 & 27 & 1.215 & 10.38 & 6.75 \\
\hline 2 & Macaranga denticulata & 1 & 0 & 0 & 0 & 1 & 0.045 & 0.38 & 0.25 \\
\hline 3 & Maesa chisia & 6 & 10 & 7 & 0 & 23 & 1.035 & 8.85 & 5.75 \\
\hline 4 & Arundinaria falcata & 1 & 20 & 0 & 0 & 21 & 0.945 & 8.08 & 5.25 \\
\hline 5 & Actinodaphne anguistifolia & 1 & 0 & 0 & 0 & 1 & 0.045 & 0.38 & 0.25 \\
\hline 6 & Litsea elongeta & 21 & 0 & 6 & 0 & 27 & 1.215 & 10.38 & 6.75 \\
\hline 7 & Rhus succedanes & 1 & 1 & 0 & 0 & 2 & 0.09 & 0.77 & 0.5 \\
\hline 8 & Toona ciliata & 3 & 1 & 0 & 0 & 4 & 0.18 & 1.54 & 1 \\
\hline 9 & Caesalpinia decapitala & 1 & 0 & 1 & 0 & 2 & 0.09 & 0.77 & 0.5 \\
\hline 10 & Schima wallichii & 3 & 1 & 5 & 8 & 17 & 0.765 & 6.54 & 4.25 \\
\hline 11 & Persea ghamblei & 2 & 0 & 1 & 0 & 3 & 0.135 & 1.15 & 0.75 \\
\hline 12 & Acer oblongum & 14 & 0 & 0 & 19 & 33 & 1.485 & 12.69 & 8.25 \\
\hline 13 & Rhus javanica & 2 & 0 & 1 & 0 & 3 & 0.135 & 1.15 & 0.75 \\
\hline 14 & Caryopteris odorata & 56 & 1 & 4 & 4 & 65 & 2.925 & 25 & 16.25 \\
\hline 15 & Myrica esculanta & 0 & 1 & 0 & 0 & 1 & 0.045 & 0.38 & 0.25 \\
\hline 16 & Albizzia chinensis & 0 & 0 & 6 & 0 & 6 & 0.27 & 2.31 & 1.5 \\
\hline 17 & Symplocus pyrifolia & 0 & 0 & 1 & 6 & 7 & 0.315 & 2.69 & 1.75 \\
\hline \multirow[t]{2}{*}{18} & Pinus wallichiana & 0 & 0 & 0 & 18 & 18 & 0.81 & 6.92 & 4.5 \\
\hline & Total & 111 & 43 & 51 & 55 & 260 & 11.7 & 100 & 65.25 \\
\hline
\end{tabular}

Table 9. Abundance and diversity indices.

\begin{tabular}{|c|c|c|c|c|c|c|c|c|}
\hline \multirow{2}{*}{ Species name } & \multirow{2}{*}{ Observed abundance } & \multirow{2}{*}{$\%$} & \multicolumn{2}{|c|}{ Shannon's Diversity } & \multicolumn{3}{|c|}{ Simpson } & \multirow[b]{2}{*}{ Di } \\
\hline & & & $\ln \mathrm{pi}$ & pi (ln pi) & pi(ln pi)2 & ni(ni - 1) & $\mathrm{N}(\mathrm{N}-1)$ & \\
\hline Alnus nepalensis & & & -2.89037 & -0.16058 & 0.464125 & 2 & 1260 & 0.001587 \\
\hline Acer oblongum & 2 & 5.56 & -2.89037 & -0.16058 & 0.464125 & 2 & 1260 & 0.001587 \\
\hline Actinodaphne anguistifolia & 1 & 2.78 & -3.58352 & -0.09954 & 0.356711 & 0 & 1260 & 0 \\
\hline Albizzia chinensis & 1 & 2.78 & -3.58352 & -0.09954 & 0.356711 & 0 & 1260 & 0 \\
\hline Arundinaria falcata & 2 & 5.56 & -2.89037 & -0.16058 & 0.464125 & 2 & 1260 & 0.001587 \\
\hline Caesalpinia decapitala & 2 & 5.56 & -2.89037 & -0.16058 & 0.464125 & 2 & 1260 & 0.001587 \\
\hline Caryopteris odorata & 4 & 11.11 & -2.19722 & -0.24414 & 0.536422 & 12 & 1260 & 0.009524 \\
\hline Litsea elongeta & 2 & 5.56 & -2.89037 & -0.16058 & 0.464125 & 2 & 1260 & 0.001587 \\
\hline Macaranga denticulata & 1 & 2.78 & -3.58352 & -0.09954 & 0.356711 & 0 & 1260 & 0 \\
\hline Maesa chisia & 3 & 8.33 & -2.48491 & -0.20708 & 0.514563 & 6 & 1260 & 0.004762 \\
\hline Myrica esculanta & 1 & 2.78 & -3.58352 & -0.09954 & 0.356711 & 0 & 1260 & 0 \\
\hline Persea ghamblei & 2 & 5.56 & -2.89037 & -0.16058 & 0.464125 & 2 & 1260 & 0.001587 \\
\hline Pinus wallichiana & 1 & 2.78 & -3.58352 & -0.09954 & 0.356711 & 0 & 1260 & 0 \\
\hline Rhus javanica & 2 & 5.56 & -2.89037 & -0.16058 & 0.464125 & 2 & 1260 & 0.001587 \\
\hline Rhus succedanes & 2 & 5.56 & -2.89037 & -0.16058 & 0.464125 & 2 & 1260 & 0.001587 \\
\hline Schima wallichii & 4 & 11.11 & -2.19722 & -0.24414 & 0.536422 & 12 & 1260 & 0.009524 \\
\hline Symplocus pyrifolia & 2 & 5.56 & -2.89037 & -0.16058 & 0.464125 & 2 & 1260 & 0.001587 \\
\hline Toona ciliata & 2 & 5.56 & -2.89037 & -0.16058 & 0.464125 & 2 & 1260 & 0.001587 \\
\hline
\end{tabular}


In previous study in 1995, altogether 20 species were recorded in 0.16 ha area with Litsea chartacea and Maesa chisia species covering highest abundance (9.67\%) while each of the 11 species were found covering lowest abundance (3.22\%) and the rest of 7 species were recorded covering $6.45 \%$ abundance each. The result reveals in 1995 there was diversity in species composition without dominance of single species (Table 10).

Table 10 represents Shannon's and Simpson Diversity for 18 species recorded in this study and 20 species in pervious study within an area of 0.16 ha. The Shannon's and Simpson's diversity value were higher in 1995 compare to the present study (Table 11).

\subsubsection{Basal Area and Timber Volume}

In 3 quadrates studied in natural forests, total 61 trees belonging to 9 genera and 9 species were recorded. Quadrate 2 composed of highest number of species (5) with lowest basal area $\left(2.3 \mathrm{~m}^{2}\right)$ and tree volume $\left(11.43 \mathrm{~m}^{3}\right)$ while quadrate 3 was found with lowest number of species together with highest basal area $\left(6.2 \mathrm{~m}^{2}\right)$ and tree volume $\left(62.47 \mathrm{~m}^{3}\right.$ ) (Table 12$)$.

\section{Discussion}

The environmental impacts in the study area observed at range of spatial and temporal scales. Temporal fluctuations of environmental factors change biodiversity constantly over different scales. Natural population and communities of taxa turnover means origination and extinction predominantly in global scales, and colonization and disappearance at local to continental scale [38].

Table 10. Species diversity of trees and shrubs in the sampling plots in 1995.

\begin{tabular}{|c|c|c|c|c|c|c|c|c|}
\hline \multirow{2}{*}{ Species name } & \multirow{2}{*}{ Observed abundance } & \multirow{2}{*}{$\%$ Abd. } & \multicolumn{3}{|c|}{ Shannon's } & \multicolumn{3}{|c|}{ Simpson } \\
\hline & & & $\ln \mathrm{pi}$ & pi (ln pi) & pi(ln pi)2 & ni(ni - 1) & $\mathrm{N}(\mathrm{N}-1)$ & Di \\
\hline Acer oblongum & 2 & 6.45 & -2.74084 & -0.17683 & 0.484658 & 2 & 930 & 0.002151 \\
\hline Actinodaphne anguistifolia & 2 & 6.45 & -2.74084 & -0.17683 & 0.484658 & 2 & 930 & 0.002151 \\
\hline Alnus nepalensis & 2 & 6.45 & -2.74084 & -0.17683 & 0.484658 & 2 & 930 & 0.002151 \\
\hline Caryopteris odorata & 1 & 3.23 & -3.43399 & -0.11077 & 0.380396 & 0 & 930 & 0 \\
\hline Leucosceptrum canum & 1 & 3.23 & -3.43399 & -0.11077 & 0.380396 & 0 & 930 & 0 \\
\hline Litsea chartacea & 3 & 9.68 & -2.33537 & -0.226 & 0.527804 & 6 & 930 & 0.006452 \\
\hline Litsea doshia & 2 & 6.45 & -2.74084 & -0.17683 & 0.484658 & 2 & 930 & 0.002151 \\
\hline Litsea elongate & 1 & 3.23 & -3.43399 & -0.11077 & 0.380396 & 0 & 930 & 0 \\
\hline Lyonia ovlifolia & 1 & 3.23 & -3.43399 & -0.11077 & 0.380396 & 0 & 930 & 0 \\
\hline Macaranga denticulata & 1 & 3.23 & -3.43399 & -0.11077 & 0.380396 & 0 & 930 & 0 \\
\hline Maesa chisia & 3 & 9.68 & -2.33537 & -0.226 & 0.527804 & 6 & 930 & 0.006452 \\
\hline Persea gamblei & 2 & 6.45 & -2.74084 & -0.17683 & 0.484658 & 2 & 930 & 0.002151 \\
\hline Pinus roxburgii & 1 & 3.23 & -3.43399 & -0.11077 & 0.380396 & 0 & 930 & 0 \\
\hline Pinus wallichiana & 1 & 3.23 & -3.43399 & -0.11077 & 0.380396 & 0 & 930 & 0 \\
\hline Quercus leucotrichophora & 2 & 6.45 & -2.74084 & -0.17683 & 0.484658 & 2 & 930 & 0.002151 \\
\hline Rhododendron arboretum & 1 & 3.23 & -3.43399 & -0.11077 & 0.380396 & 0 & 930 & 0 \\
\hline Rhus javanica & 2 & 6.45 & -2.74084 & -0.17683 & 0.484658 & 2 & 930 & 0.002151 \\
\hline Schima wallichii & 1 & 3.23 & -3.43399 & -0.11077 & 0.380396 & 0 & 930 & 0 \\
\hline Symplocus pyrifolia & 1 & 3.23 & -3.43399 & -0.11077 & 0.380396 & 0 & 930 & 0 \\
\hline Toona cialiata & 1 & 3.23 & -3.43399 & -0.11077 & 0.380396 & 0 & 930 & 0 \\
\hline
\end{tabular}

Source: EIA Study 1995, IUCN Nepal. 
Table 11. Shannon's and Simpson's indices of pre and post period.

\begin{tabular}{cccccc}
\hline & \multicolumn{3}{c}{ Shannon's Diversity } & \multicolumn{2}{c}{ Simpson's } \\
\cline { 2 - 6 } Period & H' & E & Var H' & D & $1 / \mathrm{D}$ \\
\hline 2015 & 2.799 & 0.967 & -0.002 & 0.034 & 25.2 \\
1995 & 2.909 & 0.971 & -0.0043 & 0.028 & 35.77 \\
\hline
\end{tabular}

Table 12. Basal area and volume of tree species in sampling plots $\left(20 \times 30 \mathrm{~m}^{2}\right)$.

\begin{tabular}{|c|c|c|c|c|c|c|}
\hline Plots & SN & Scientific Name & Local Name & No. & BA $\left(\mathbf{m}^{2}\right)$ & Timber Volume $\left(\mathrm{m}^{3}\right)$ \\
\hline \multirow{4}{*}{1} & 1 & Toona ciliata & Tooni & 2 & 0.21 & 0.63 \\
\hline & 2 & Litsea elongeta & Pahale & 10 & 4.64 & 16.77 \\
\hline & 3 & Actinodaphne anguistifolia & Jhankri kath & 1 & 0.07 & 0.14 \\
\hline & 4 & Rhus javanica & Bhalayo & 1 & 0.79 & 4.71 \\
\hline \multicolumn{4}{|c|}{ Total } & 14 & 5.71 & 22.26 \\
\hline \multirow{5}{*}{2} & 1 & Rhus javanica & Bhalayo & 1 & 0.07 & 0.18 \\
\hline & 2 & Myrica esculanta & Kafal & 1 & 0.2 & 0.79 \\
\hline & 3 & Alnus nepalnesis & Utis & 2 & 0.6 & 3.4 \\
\hline & 4 & Macarabga denticulata & Malato & 2 & 1.01 & 4.48 \\
\hline & 5 & Toona ciliata & Tooni & 1 & 0.43 & 2.58 \\
\hline \multirow{4}{*}{3} & & Total & & 7 & 2.3 & 11.43 \\
\hline & 1 & Pinus wallichiana & Rani Sallo & 17 & 5.28 & 62.01 \\
\hline & 2 & Schima wallichii & Chilaone & 2 & 0.92 & 0.46 \\
\hline & & Total & & 61 & 6.2 & 62.47 \\
\hline
\end{tabular}

Structuring of the forest communities is influence by the disturbance, as an important factor [39] and different types and level of disturbances have a differential impact on forest communities [40]. Human pressures with development activities and other biotic components are detrimental for the vegetation structure of forests. The upper Bhotekoshi hydropower project area has recorded high species diversity before the project construction but this study shows that the decreasing trend of species composition and diversity of plant species over long temporal scales (Table 13). The study area was modified by the hydropower development activities which might become a greater cause of species extinction and direct habitat destruction.

According to the pervious study, (EIA of UBHP, 1995), Alnus nepalensis was recorded with the highest relative dominance followed by Pinus roxburgii and Litsea chartacea on the basis of the basal area. Pinus wallichiana was recorded with the highest importance value which may be attributed to its pure stand in a localized area. Likewise, importance value of Alnus nepalensis and Quercus leucotrichophora were also shown exceeding the value of 26, while Lyonia ovlifolia had the lowest importance value. $41.57 \mathrm{~m}^{3}$ of total standing volume was calculated for all species in the sample plots. In terms of species, Alnus nepalensis reported covering $9 \mathrm{~m}^{3}$ followed by Pinus roxburgii $\left(6 \mathrm{~m}^{3}\right.$ ). The sample plot 3 (Forest North to Larcha) reported with the highest timber volume (nearly $13 \mathrm{~m}^{3}$ ) followed by plot 1 (forest below Panserpu village).

In this study, highest basal area $\left(5.27 \mathrm{~m}^{2}\right)$ and volume $\left(62.01 \mathrm{~m}^{3}\right)$ of Pinus wallichiana was found in plot 4 (Thulo Ban CF) followed by Schima wallichii in plot 3 (Khajilung CF). Likewise, Litsea elongeta in plot 2 (Bhairabkunda) calculated basal area of $4.63 \mathrm{~m}^{2}$ and timber volume of $16.77 \mathrm{~m}^{3}$ which is followed by Actinodaphne anguistifolia, Toona cialita and Rhus javanica in plot 1 (Panserpu forest). The plot 2 has shown the lowest calculated BA and timber volume however 1995 showed the highest timber volume. Thus, the study concludes that the Larcha forest is the most disturbed forest of the project area. 
According to EIA monitoring report, 150 trees at headwork and a tree of Michelia champaca at audit were cleared and Artemisia vulgaris, Arundinaria intermedia and Alnus nepalensis proposed as a compensatory measures for reforestation. However, the present study assessed abundant number of regenerated and planted individuals the species composition is found in decreasing trend in natural forests. Besides that, the regenerated area is found dominated by unwanted species of herbs and shrubs like Eupatorium adennophorum, Cyathula capitata and Artimesia valguris.

Beier et al., 2008 [41], found no consistent diversity overall pattern of climate change-induced decline across climate drivers, scales, or ecosystem types. Dullinger et al., 2012 [42] argue that the reduction in diversity, often caused by range contractions driving long-term extinctions due to significant climatic effect. As the study area belongs to the temperate region, an exception to this pattern is expected at high elevations, where temperature limits to many species [43], so diversity should respond favorably to warming [44].

Floristic composition and species diversity in pervious and this study revealed changes on species, genera and family at the ratio of 2:1:2. Similarly, Simpsons index (D), Shannon's Diversity (H) and Species equitability (E) are also found decreasing at the ratio of $-0.014: 40.0419: 007$ (Figure 4).

Table 13. Comparative Analysis of forest and vegetation in natural forest of the project area before (Project Construction) and after (Project Implementation).

\begin{tabular}{|c|c|c|c|c|}
\hline Sampling Size & Pervious Study 1995 & Present Study & Difference & Impact of Change \\
\hline Number of Quadrates & 4 & 4 & No & - \\
\hline Total Area & $1600 \mathrm{~m}^{2}$ & $1600 \mathrm{~m}^{2}$ & No & - \\
\hline Total Numbers of Species & 20 & 18 & 2 & Decreasing trend of sps \\
\hline Total Numbers of Genera & 18 & 17 & 1 & Change \\
\hline Total Numbers of Family & 15 & 13 & 2 & Change \\
\hline \multicolumn{5}{|l|}{ Diversity Index } \\
\hline Simpson’s index (D)- & 0.027 & 0.039 & -0.014 & Decreasing \\
\hline Shannon’s Diversity (H)- & 2.908 & 2.879 & 0.041 & Decreasing \\
\hline Shannon's Max (Hmax)- & 2 & 2 & 0 & No change \\
\hline Species equitability (E)- & 0.9753 & 0.9683 & 0.007 & Decreasing \\
\hline
\end{tabular}

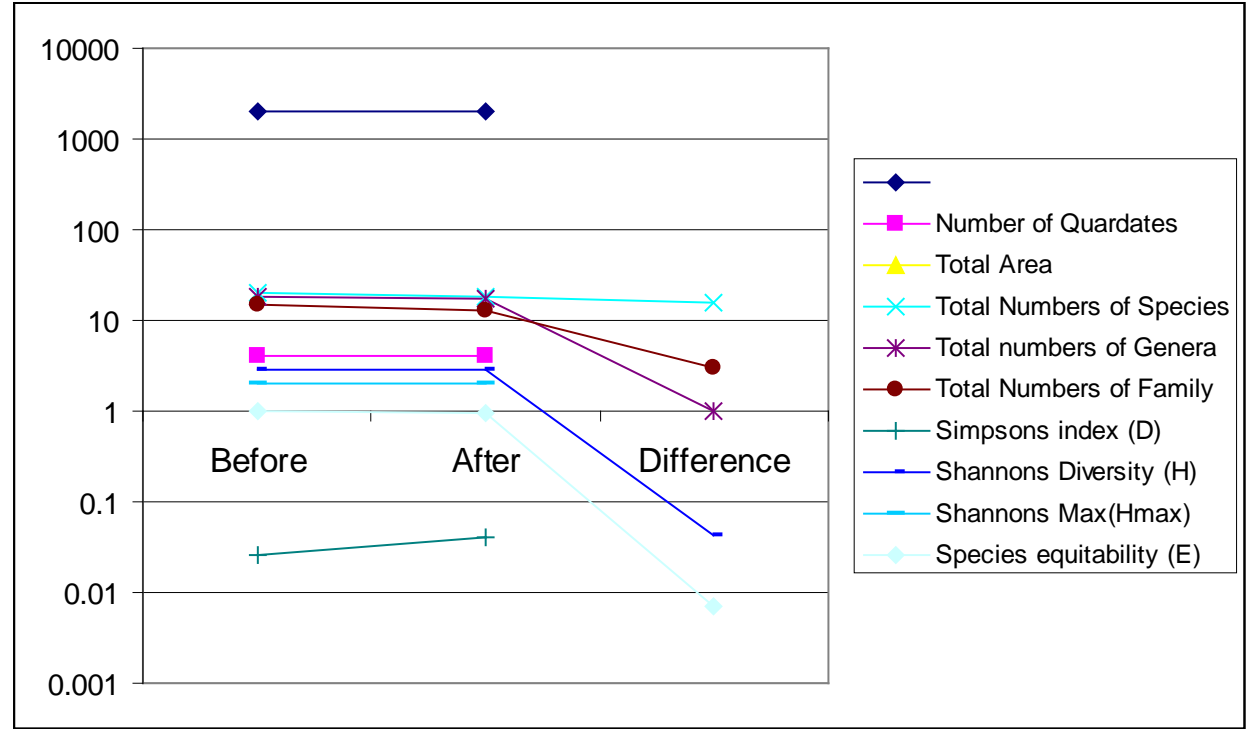

Figure 4. Changing pattern on floristic composition and species diversity over long temporal scales. 


\subsection{Analysis of Regeneration Properties}

The regeneration properties of the vegetation plots showed relatively at stable state (with canopy and sub-canopy species regenerating) while other plots are at transitional stage, possibly due to disturbance. It is apparent that once disturbed plots can regenerate to a forest environment based on time-series data. Regenerating and tree recruitment appeared to be difficult in previously disturbed plots forest due to dominance of shrub layer. However, no new endemic, or invasive, species were recorded in the regenerating areas; abundance of unwanted species was observed. According to F. Stuart Chapin, et al., 2000 [45], biodiversity can influence the ability of exotic species to attack communities through either cumulative effect of species richness or the influence of traits of resident species. This could be the fact of cumulative impact of the project for observing only 15 species compared to previous study. Thus, the fact implicates the artificial conservation of forest species could never be recovered to the natural forest condition with species diversity.

\subsection{Analysis of Natural Forest}

The natural forest studied comprises community forests managed by the local communities. According to Shrestha and Paudel, 1996 [46] and Kunwar, 2002 [47], generally local people access to government managed forests while protect their community forests.

Strengthening local control, strongly implementation of EIA mitigation measures in project influence area and policy oversight is urgently needed to assure long-term sustainability of the project and maintaining integrity of the local environment [48]. As reported in EIA study 1995, 4 community forests were reported with rich biodiversity which were under extensive pressure along with increasing development activities. To minimize these impacts in the forest area, EIA study proposed mitigation measures like reforestation and management activities in disturbed slopes. The present study revealed decreasing number of species biodiversity due to modified environment and increased pressure on forest and vegetation. Species diversity with their number and kinds of species has functional consequences to determine the organismal traits that influence ecosystem processes (Chapin, F. Stuart et al., 2000). The diversity indices in Figure 5 showed loss of $20 \%$ species diversity after the project disturbance (Figure 5). This could be the outcome of improper implementation of mitigation measures and policy sought out.

Despite the increasing area for quadrate sample, there is still lack of rich biodiversity in regenerated or planted area however Ecologists have produced hundreds of examples of increasing species diversity with increasing area [49]. Yet there are numerous empirical examples, where debate continues to exist over the cause (s) of the species-area relation [50].

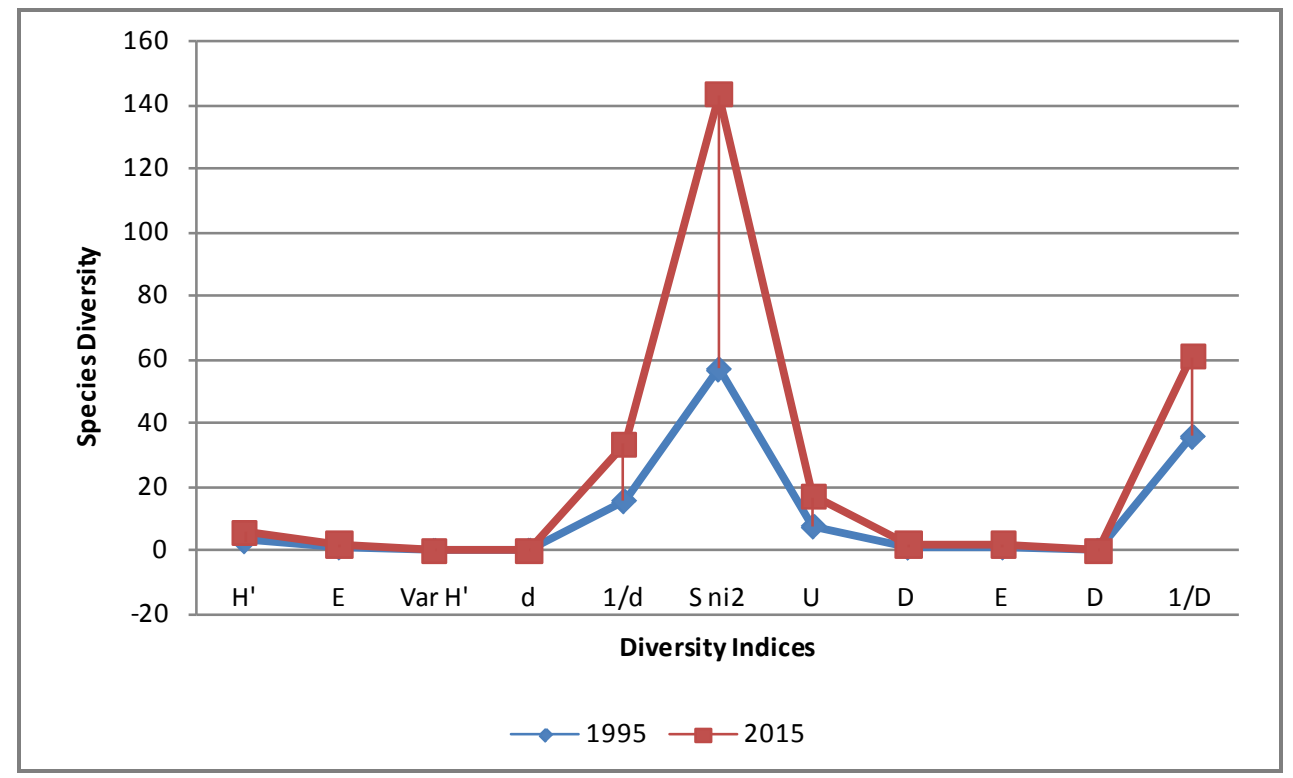

Figure 5. Differences in species diversity pre and post study. 
The local and regional climate, topographic position, disturbances, environmental factors and biotic interactions determine forest structure and composition [51]. Vegetation disturbance, especially grazing, increases species richness in some situations, due to the greater occurrence of non-endemic species [52]. Likewise, low intensity and sustained human disturbance through selective logging, firewood extraction, grazing and land clearing for permanent agriculture may influence plant communities and their succession patterns [53] [54].

Thus, the low regeneration properties in the project influence area could be assume due to immense disturbance and varied range of requirements to tolerate the environmental condition. The long term capacity of forests to maintain biodiversity is the global concern for supply of goods and services (including carbon storage, food, clean water, and recreation). It is augmented following pragmatic impacts occurring to global forests as a result of climate change [55]-[58].

Abiotic factors plays important role to change species composition and reduction of the diversity. Similarly, different pathways of climatic effects on multiple species results habitat effects and differing effects of invasions at local vs regional to global scales [59]. The increasing and decreasing frequency and numbers of an individual species responds to a changing environment encountering one another at spatial scale. In spite of the implications of changing patterns in the temporal scale, plant community responses to climate change uncommonly, driving the scale-dependency of the factors [60] [61].

According to Zomer et al., 2001 [62], forests are declining at the fast rate with negative consequences like temperature change, land instability, soil and biodiversity and local people's dependency for livelihood. Joseph Connell, drawing in part on Henry, 1975 [63], Horn’s, 1975 [64] paper, proposed that biodiversity is highest when disturbance is neither too rare nor too frequent. Competitive exclusion by the dominant species arises with low disturbance while, only species tolerant to high frequency of disturbance can persist with high disturbance. CBD 2010 [65], page 55 depict the biggest single source of pressure creates loss of habitat and degradation of biodiversity worldwide. Mankind recognization of biodiversity with its specific role as an integral and fundamental part of the global ecosystem can be halted biodiversity loss. The prevailing human development paradigm is the root cause of all drivers of biodiversity loss which does not sufficiently respect the laws of nature and the need to integrate human economy into ecosystem functioning [66]-[68]). Thus, the study assumes that the high disturbance on forests by the development activities could be the cause for unrecovered natural integrity of forest ecosystem.

\section{Conclusions}

The study concludes that the species diversity in the study area is in declining trend with decreased species composition in both natural and regenerated forests due to intensive pressure. Abundance of Alnus nepalensis with high relative dominance followed by Pinus roxburgii and Litsea chartacea in 1995 is replaced by Litsea elongeta followed by Actinodaphne anguistifolia, Toona cialita and Rhus javanica in this study which is the result of long-term interactions between the vegetation and site factors over time and space.

The disturbed forest slopes were found with low species diversity and abundance of single species. Moreover, growth of unwanted or alien species found spreading over the regenerated area. An ineffective implementation of policies, slight overlook of the impacts and prediction methods, absence of major changes in policy and human behavior, effects on the environment will continue to alter biodiversity, change land-use and increase atmospheric $\mathrm{CO}_{2}$. Thus, effective management of forest with intensive control on human disturbance could protect the natural integrity of forest ecosystem.

\section{References}

[1] Groombridge, B. and Jenkins, M.D. (2002) World Atlas of Biodiversity. Prepared by the UNEP World Conservation Monitoring Centre, University of California Press, Berkeley.

[2] Clements, F.E. (1920) Plant Succession: An Analysis of the Development of Vegetation. Carnegie Institute, Washington DC, 388 p, Publication No. 290.

[3] Braun-Blanquet, J. (1932) Plant Sociology: The Study of Plant Communities. McGraw-Hill, New York, 439 p.

[4] Odum, E.P. (1971) Fundamentals of Ecology. 3rd Edition, Saunders, Philadelphia, 574 p.

[5] Jalas, J. (1955) Hemerobe und hemerochore Pflanzenarten. Ein terminologischer Reformversuch. Acta Societatis pro Fauna et Flora Fennica, 72, 1-15. 
[6] Sukopp, H. (1969) Der Einfluss des Menschen auf die Vegetation. Vegetation, 17, 360-371.

[7] Kowarik, I. (1988) Zum menschlichen Einfluss auf Flora und Vegetation. Theoretische Konzepte und ein Quantifizierungsansatz am Beispiel von Berlin (West). Landschaftsentwicklung und Umweltforschung, 56, 1-280.

[8] Kowarik, I. (1990) Some Responses of Flora and Vegetation to Urbanization in Central Europe. In: Sukopp, H., Hejný, S. and Kowarik, I., Eds., Urban Ecology: Plants and Plant Communities in Urban Environments, SPB Academic Publishing, The Hague, 45-74.

[9] Reif, A. (2000) Das naturschutzfachliche Kriterium der Naturnaehe und seine Bedeutung fuer die Waldwirtschaft. Zeitschrift für Ökologie und Naturschutz, 8, 239-250.

[10] Karki, M.B. (1991) The Rehabilitation of Forestland in Nepal. Natural Resources, 27, 38-46.

[11] Chaudhary, R.P. and Kunwar, R.M. (2002) Vegetation Composition of Arun Valley, East Nepal. In: Chaudhary, R.P., Subedi, B.P., Vetaas, O.R. and Aase, T.H., Eds., Vegetation and Society: Their Interaction in the Himalayas, Tribhuvan University, Kathmandu and University of Bergen, Norway, 38-55.

[12] Geldenhuys, C.J. and Murray, B. (1993) Floristic and Structural Composition of Hanglip Forest in the Southpansberg, Northern Transvaal. Southern African Forestry Journal, 165, 9-20.

[13] Longman, K.A. and Jenik, J. (1987) Tropical Forests and Its Environment. Longman Publishers, Singapur, 347 p.

[14] Holdridge, L.R. (1967) Life Zone Ecology. Tropical Science.

[15] Prentice, I.C., Cramer, W.P., Harrison, S.P., Leemans, R., Monserud, R.A. and Solomon, A.M. (1993) Special Paper: A Global Biome Model Based on Plant Physiology and Dominance, Soil Properties and Climate. Journal of Biogeography, 19, 117-134. http://dx.doi.org/10.2307/2845499

[16] Stainton, J.D.A. (1972) Forests of Nepal. John Murray, London.

[17] Chaudhary, R.P. (1998) Biodiversity in Nepal: Status and Conservation. Craftsman Press, Bangkok.

[18] Newton, A.C., Cayuela, L., Echeverría, C., Armesto, J.J., Del Castillo, R.F., Golicher, D., Geneletti, D., Gonzalez-Espinosa, M., Huth, A., López-Barrera, F., Malizia, L., Manson, R., Premoli, A., Ramírez-Marcial, N., Rey Benayas, J.-M., Rüger, N., Smith-Ramírez, C. and Williams-Linera, G. (2009) Toward Integrated Analysis of Human Impacts on Forest Biodiversity: Lessons from Latin America. Ecology and Society, 14, 2.

[19] IAIA (1999) Principles of Environmental Impact Assessment Best Practice. International Association of Impact Assessment and the Institute of Environmental Assessment (IAIA).

[20] Newton, A.C. (2007) Biodiversity Loss and Conservation in Fragmented Forest Landscapes: The Forests of Montane Mexico and Temperate South America. CABI, Wallingford and Oxford. http://dx.doi.org/10.1079/9781845932619.0000

[21] FAO (2006) The Global Forest Resources Assessment. Food and Agriculture Organization (FAO), Rome.

[22] Millennium Ecosystem Assessment (MEA) (2005) Ecosystems and Human Well-Being: Current State and Trends. Island Press, Washington DC.

[23] Golicher, D. and Newton, A.C. (2007) Applying Succession Models to the Conservation of Tropical Montane Forest. In: Newton, A.C., Ed., Biodiversity Loss and Conservation in Fragmented Forest Landscapes: The Forests of Montane Mexico and Temperate South America, CABI, Wallingford and Oxfordshire, 200-222. http://dx.doi.org/10.1079/9781845932619.0200

[24] Rüger, N., Armesto, J.J., Gutiérrez, A.G., Williams-Linera, G. and Huth, A. (2007a) Process-Based Modeling of Regeneration Dynamics and Sustainable Use in Species-Rich Rainforests. In: Newton, A.C., Ed., Biodiversity Loss and Conservation in Fragmented Forest Landscapes: The Forests of Montane Mexico and Temperate South America, CABI, Wallingford and Oxfordshire, 244-275. http://dx.doi.org/10.1079/9781845932619.0244

[25] Rüger, N., Guitierrez, A.G., Kissling, W.D., Armesto, J.J. and Huth, A. (2007b) Ecological Impacts of Harvesting Options for Temperate Evergreen Rain Forest in Southern Chile-A Simulation Experiment. Forest Ecology and Management, 252, 52-66. http://dx.doi.org/10.1016/j.foreco.2007.06.020

[26] Rüger, N., Williams-Linera, G., Kissling, W.D. and Huth, A. (2008) Long-Term Impacts of Fuel Wood Extraction on a Mexican Cloud Forest. Ecosystems, 11, 868-881. http://dx.doi.org/10.1007/s10021-008-9166-8

[27] IUCN (1995) Environment Impact Assessment (EIA) of Upper Bhotekoshi Hydropower Project, Sindhupalchowk District. International Union of Conservation of Nature, Nepal.

[28] Mueller-Dombois, D. and Ellenberg, H. (1974) Aims and Methods of Vegetation Ecology. John Wiley and Sons, New York, $547 \mathrm{p}$.

[29] DPR (2000) Flowering Plants of Nepal (Phanerogams). Department of Plant Resources, Government of Nepal, Kathmandu, N 2000, 399 p.

[30] Whittaker, R.H. (1976) Evolution and Measurement of Species Diversity. Taxon, 21, 231-251. 
[31] Shannon, C.E. and Weiner, W. (1963) The Mathematical Theory of Communication. University of Illinois Press, Urbana, 117.

[32] Simpson, E.M. (1949) Measurement of Diversity. Nature, 163, 688. http://dx.doi.org/10.1038/163688a0

[33] Hill, M.O. (1973) Diversity and Evenness: A Unifying Notation and Its Consequences. Ecology, 54, 427-432. http://dx.doi.org/10.2307/1934352

[34] GoN/Earth Science (1984) Land Resource Mapping Project. Department and Kenning Earth Science Ltd., Canada.

[35] Zobel, D.B., Jha, P.K., Behan, M.J. and Yadav, U.K.R. (1987) A Practical Manual for Ecology. Ratna Book Distributors, Kathmandu, $150 \mathrm{p}$.

[36] Preston, R.W. (1962) The Canonical Distribution of Commonness and Rarity: Part I. Ecology, 43, 185-215. http://dx.doi.org/10.2307/1931976

[37] Bhatt, R. (2010) Vegetation Analysis and Differences in Local Environment Variables in Indrawati Hydropower Project Areas in Nepal. International Research Journal: Plant Science, 1, 83-94.

[38] Goetze, D., Karlowski, U., Tockner, K., Watve, A., Riede, K. and Porembski, S. (2008) Spatial and Temporal Dimensions of Biodiversity Dynamics. In: Barthlott, W., Linsenmaier, K.E. and Porembski, S., Eds., Biodiversity: Structure and Function, Encyclopedia of Life Support Systems (EOLSS), UNESCO, Oxford, 166-208.

[39] Foster, R.B. (1980) Heterogeneity and Disturbance in Tropical Vegetation. In: Soule, M.E. and Wilox, B.A., Eds., Conservation Biology: An Evolutionary Ecological Perspective, Sinauer Associates, Sunderland, 75-92.

[40] Halpern, C.B. and Spies, T.A. (1975) Plant Species Diversity in Natural and Managed Forests of the Pacific Northwest. Ecological Applications, 5, 913-934. http://dx.doi.org/10.2307/2269343

[41] Beier, C., Emmett, B.A., Penuelas, J., Schmidt, I.K., Tietema, A., Estiarte, M., Gundersen, P., et al. (2008) Carbon and Nitrogen Cycles in European Ecosystems Respond Differently to Global Warming. Science of the Total Environment, 407, 692-697. http://dx.doi.org/10.1016/j.scitotenv.2008.10.001

[42] Dullinger, S., Gattringer, A., Thuiller, W., Moser, D., Zimmermann, N.E., Guisan, A., Willner, W., et al. (2012) Extinction Debt of High-Mountain Plants under 21st Century Climate Change. Nature Climate Change, 2, 619-622. http://dx.doi.org/10.1038/nclimate1514

[43] Grabherr, G., Gottfried, M. and Pauli, H. (1994) Climate Effects on Mountain Plants. Nature, 369, 448. http://dx.doi.org/10.1038/369448a0

[44] Theurillat, J.P. and Guisan, A. (2001) Potential Impact of Climate Change on Vegetation in the European Alps: A Review. Climatic Change, 50, 77-109. http://dx.doi.org/10.1023/A:1010632015572

[45] Chapin III, F.S., Zavaleta, E.S., Eviner, V.T., Naylor, R.L., Vitousek, P.M., Reynolds, H.L., Hooper, D.U., Lavorel, S., Sala, O.E., Hobbie, S.E., Mack, M.C. and Díaz, S. (2000) Consequences of Changing Biodiversity. Nature, 405, $234-$ 242. http://dx.doi.org/10.1038/35012241

[46] Shrestha, R.K. and Paudel, K.C. (1996) Oak Forest under Threat: An Urgent Concern for the Mountain Environment. In: Jha, P.K., Ghimire, G.P.S., Karmacharya, S.B., Baral, S.R. and Lacoul, P., Eds., Environment and Biodiversity: In the Context of South Asia, ECOS, Kathmandu, 114-119.

[47] Kunwar, R.M. (2002) Participation and Benefits to Local People in Community Forestry: A Case from Makawanpur District, Nepal. Thesis, Indian Institute of Forest Management, Bhopal, 93 p.

[48] Bhatt, R. and Khanal, S. (2009) Environmental Impact Assessment System in Nepal: An Overview of Policy, Legal Instruments and Process. Kathmandu University Journal of Science, Engineering and Technology, 5, 160-170.

[49] Rosenzweig, M.L. (1995) Species Diversity in Space and Time. Cambridge University Press, Cambridge. http://dx.doi.org/10.1017/cbo9780511623387

[50] McGuinness, K.A. (1984) Equations and Explanations in the Study of Species-Area Curves. Biological Review, 59, 423-440. http://dx.doi.org/10.1111/j.1469-185X.1984.tb00711.x

[51] Spurr, H.R. and Barnes, B.V. (1980) Forest Ecology. 3rd Edition, John Wiley, New York.

[52] Green, D.M. and Kauffman, J.B. (1995) Succession and Livestock Grazing in a Northeast Oregon Riparian Ecosystem. Journal of Range Management, 48, 307-313. http://dx.doi.org/10.2307/4002482

[53] Attiwill, P.M. (1994) The Disturbance of Forest Ecosystems: The Ecological basis for Conservative Management. Forest Ecology and Management, 63, 247-300. http://dx.doi.org/10.1016/0378-1127(94)90114-7

[54] Fujisaka, S., Escobar, G. and Veneklass, E. (1998) Plant Community Diversity Relative to Human Land Uses in Amazon Forest Colony. Biodiversity and Conservation, 1, 41-57.

[55] Phillips, O.L. (1997) The Changing Ecology of Tropical Forests. Biodiversity and Conservation, 6, $291-311$.

http://dx.doi.org/10.1023/A:1018352405482 
[56] Kellomaki, S., Peltola, H., Nuutinen, T., Korhonen, K.T. and Strandman, H. (2008) Sensitivity of Managed Boreal Forests in Finland to Climate Change, with Implications for Adaptive Management. Philosophical Transactions of the Royal Society B, 363, 2341-2351. http://dx.doi.org/10.1098/rstb.2007.2204

[57] Phillips, S.J., Dudík, M., Elith, J., Graham, C.H., Lehmann, A., Leathwick, J. and Ferrier, S. (2009) Sample Selection Bias and Presence-Only Distribution Models: Implications for Background and Pseudo-Absence Data. Ecological Applications, 19, 181-197. http://dx.doi.org/10.1890/07-2153.1

[58] Malhi, Y., Aragão, L.E.O.C., Galbraith, D., Huntingford, C., Fisher, R., Zelazowski, P., Sitch, S., McSweeney, C. and Meir, P. (2009) Exploring the Likelihood and Mechanism of a Climate-Change-Induced Dieback of the Amazon Rainforest. Proceedings of the National Academy of Sciences of the United States of America, 106, 20610-20615. http://dx.doi.org/10.1073/pnas.0804619106

[59] Gornish, E. and Tylianakis, J.M. (2013) Community Shift under Climate Change: Mechanism at Multiple Scales. American Journal of Botany, 100, 1422-1434. http://dx.doi.org/10.3732/ajb.1300046

[60] Leuzinger, S., Luo, Y., Beler, C., Dileleman, W., Vicca, S. and Korner, C. (2011) Do Global Change Experiments Overestimate Impacts on Terrestrial Ecosystems? Trends in Ecology \& Evolution, 26, 236-241. http://dx.doi.org/10.1016/j.tree.2011.02.011

[61] Chave, J. (2013) The Problem of Pattern and Scale in Ecology: What Have We Learned in 20 Years? Ecology Letters, 16, 4-16.

[62] Zomer, R., Ustin, S.L. and Carpenter, C.C. (2001) Land Cover Change along Tropical and Subtropical Riparian Corridors within the Makalu Barun National Park and CA, Nepal. Mountain Research and Development, 21, 175-184. http://dx.doi.org/10.1659/0276-4741(2001)021[0175:LCCATA]2.0.CO;2

[63] Horn, H.S. (1975) Forest Succession. Scientific American, 232, 90-98. http://dx.doi.org/10.1038/scientificamerican0575-90

[64] Horn, H.S. (1975) Markovian Properties of Forest Succession. In: Cody, M.L. and Diamond, J.M., Eds., Ecology and Evolution of Communities, Belknap Press, Massachusetts, 196-211.

[65] CBD (2010) Secretariat of the Convention on Biological Diversity, Global Biodiversity Outlook 3. Montréal, 94p.

[66] CBD (2009a) Convention on Biological Diversity. COP 9, Bonn.

[67] CBD (2009b) Convention on Biological Diversity. Revision and Updating of the Strategic Plan: Possible Outline and Elements of the New Strategic Plan.

[68] Mace, G.M., et al. (2010) Biodiversity Targets after 2010. Current Opinion in Environmental Sustainability, 2, 3-8. http://dx.doi.org/10.1016/j.cosust.2010.03.003 